\title{
Liver oxidative stress of the grey mullet Mugil cephalus presents seasonal variations in Ennore estuary
}

\author{
E. Padmini, B. Vijaya Geetha and M. Usha Rani \\ Department of Biochemistry, Bharathi Women's College, Chennai-108, Tamilnadu, India \\ Correspondence to: E. Padmini, Department of Biochemistry, Bharathi Women's College, Chennai-600 \\ 108, Tamilnadu, India \\ Fax: +91-44-2528-0473. E-mail: dstpadmini@rediffmail.com
}

\begin{abstract}
The objective of this study was to determine the liver oxidative stress status of grey mullets living in heavy-metal-rich polluted Ennore estuary compared with unpolluted Kovalam estuary. Fish were collected from both estuaries during the monsoon and summer seasons from October 2004 to September 2006. Fish liver homogenate ( $N=20$ per group) was prepared for evaluating oxidative stress parameters. Fish living in the polluted estuary had significantly higher lipid oxidation products, conjugated dienes $\left(0.346 \pm 0.017\right.$ vs $0.141 \pm 0.012 \Delta \mathrm{A}_{233} / \mathrm{mg}$ protein), lipid hydroperoxides $(0.752 \pm 0.032 \mathrm{vs} 0.443 \pm 0.03 \mathrm{nmol} / \mathrm{mg} \mathrm{protein})$, and lipid peroxides ( $3.447 \pm 0.14 \mathrm{vs} 1.456 \pm 0.096 \mathrm{nmol} \mathrm{MDA} / \mathrm{mg}$ protein) than those of the unpolluted estuary during the summer. In contrast, significantly lower levels of superoxide dismutase (20.39 \pm 1.14 vs $53.63 \pm 1.48$ units/mg protein) and catalase (116 $\pm 6.87 \mathrm{vs} 153 \pm 8.92$ units/mg protein) were detected in the liver of fish from the polluted estuary (Ennore) compared to fish from the unpolluted estuary (Kovalam) during the summer. Variations in most of the oxidative stress parameters were observed between the summer and monsoon seasons, indicating the importance of seasonal variation for estuaries and their inhabitants.
\end{abstract}

Key words: Antioxidant defense; Estuary; Grey mullets; Oxidative stress; Pollutants

This study is part of the DST Project Ref. No. DST: SP/SO/AS-10/2003 funded by the Ministry of Science and Technology, Government of India. M. Usha Rani is the recipient of a Junior Research Fellowship from the Council of Scientific and Industrial Research (CSIR).

Received August 13, 2007. Accepted August 22, 2008

\section{Introduction}

Estuaries, the main contributors of fisheries in India, suffer from severe damage due to increased industrialization and urbanization along the coastal areas (1). Continuous discharge of industrial effluents into the estuaries poses a serious risk for the survival of aquatics. Overloading of the estuaries with contaminants for a longer period of time has resulted in the significant buildup of pollutants with a resulting impact on water properties (2). Ennore estuary, located in the heart of the city of Chennai, India, faces this problem because it is being surrounded by polluting industries, which deposit heavy metals directly into the estuary (3). Fish are considered to be the bioindicators of marine pollution because of their ability to re- spond to pollutants (4). Oxidative stress reflects a disturbance in the pro-oxidant and antioxidant systems in favor of the pro-oxidant (5). Free radicals are the potent toxic compounds that are produced continuously in cells during exposure to environmental toxins and exert a deleterious effect via their chain reactions (6), covalent modification and oxidation of functional groups thereby causing significant damage to biological macromolecules and bringing about alterations in the cellular redox balance (7). However, the harmful effects of free radicals are blocked to a great extent by antioxidant defense systems. Seasonal variations, one of several natural biological factors, have been proposed to have a significant influence on estuaries (8). Hence, in the present study, the impact of water pollutants was examined in liver homogenate of grey mul- 
lets with respect to stress lipid oxidation markers, antioxidant enzyme activities and glutathione redox ratio as well as the influence of the summer and monsoon seasons on these parameters.

\section{Material and Methods}

\section{Chemicals}

Thiobarbituric acid, malondialdehyde, ethylenediamine tetraacetic acid, o-phthalaldehyde, $\mathrm{N}$-ethylmaleimide, and epinephrine were purchased from Sigma (USA). Hydrogen peroxide, chloroform, methanol, butylated hydroxytoluene, and cyclohexane were obtained from Sisco Research Laboratories (India). All other chemicals were of the reagent grade or equivalent.

\section{Study site and fish sampling}

Kovalam estuary, an unpolluted site located about 35 $\mathrm{km}$ south of Chennai and free from the influence of urban areas and industries, and Ennore estuary, situated about $15 \mathrm{~km}$ north of Chennai and which is highly polluted with effluents from several industries surrounding this site, were chosen for study. Contamination of Ennore estuary by heavy metals such as lead, cadmium, mercury, zinc, iron, etc., compared to Kovalam estuary has been confirmed by previous studies $(3,9)$. It has also been reported that Ennore estuary differs significantly from Kovalam estuary physically, chemically, and biologically (10).

Mugil cephalus identified by the use of FAO species identification sheets (11) was the experimental animal and the fish samples with an average length of $32-35 \mathrm{~cm}$ were collected freshly every month for two seasons from October 2004 to September 2006 from both estuaries. Fish were collected with baited minnow traps in a shallow estuary and kept in insulated containers filled with aerated estuarine water at ambient temperature $\left(25-30^{\circ} \mathrm{C}\right)$ and salinity (24-29 ppt). Fish were maintained under similar conditions for $4-5 \mathrm{~h}$ until the beginning of the experiment.

\section{Preparation of liver homogenate}

The fish were stunned by a blow on the head, and a midventral incision was made to expose the liver. Fish livers were carefully excised and washed with ice-cold saline. One gram of liver tissue was homogenized with 5 $\mathrm{mL}$ homogenizing buffer $(0.25 \mathrm{M}$ sucrose, $10 \mathrm{mM}$ Tris, $\mathrm{pH}$ 7.4, $1 \mathrm{mM}$ EDTA) and the suspension was centrifuged at $224 \mathrm{~g}$ for $10 \mathrm{~min}$. The supernatant was used for the biochemical measurements.

Analysis of oxidative stress biomarkers

Conjugated diene was determined at $233 \mathrm{~nm}$ using chloroform-methanol mixture according to the method of Rao and Recknagel (12). Lipid hydroperoxide was estimated at $560 \mathrm{~nm}$ by the method of Jiang et al. (13) in which ferrous ion oxidation was measured in the presence of xylenol orange. Levels of lipid peroxide were determined at $540 \mathrm{~nm}$ by measuring the amount of thiobarbituric acid reactive substances formed (14). Superoxide dismutase activity was assayed by monitoring the oxidation of epinephrine at $420 \mathrm{~nm}$ (15). Catalase activity was assayed at $240 \mathrm{~nm}$ by measuring the decay of hydrogen peroxide levels (16). Glutathione redox ratio was determined by spectrofluorimetric method using emission at $420 \mathrm{~nm}$ and excitation at $350 \mathrm{~nm}$ according to the method of Hissin and Hilf (17).

\section{Statistical analysis}

Data are reported as means $\pm S D$. The differences between groups and seasons were analyzed using ANOVA followed by the Duncan multiple range test. The level of statistical significance was set at $P<0.05$.

\section{Results}

\section{Effect of heavy metals on lipid oxidation products}

Exposure of fish to heavy metal pollutants increases the levels of lipid oxidation markers such as conjugated diene (Figure 1A), lipid hydroperoxide (Figure 1B) and lipid peroxide (Figure 1C) in polluted estuary fish compared with unpolluted estuary fish. The marker levels, which were increased significantly in polluted estuary fish $(P<$ $0.05)$, indicated the lipid peroxidation and damage caused by increased oxidative stress. The oxidative stress state was more severe during the summer than the monsoon season in polluted estuary fish $(P<0.05)$ with a nonsignificant difference in the results being observed between seasons in unpolluted estuary fish.

\section{Influence of heavy metals on antioxidant enzyme activities}

The activities of the antioxidant enzymes superoxide dismutase (Figure 2A) and catalase (Figure 2B) were significantly decreased $(P<0.05)$ in polluted estuary fish compared with unpolluted estuary fish. This indicates the inability of polluted estuary fish to cope with available antioxidant defense presumably due to the free radicals produced by heavy metals. Also, the observed decrease in antioxidant enzyme levels was greater during summer than during the monsoon season in polluted estuary fish ( $P$ $<0.05)$. The antioxidant enzyme levels between seasons in unpolluted estuary fish were not significantly different.

The glutathione redox ratio was decreased significantly $(P<0.05$, Figure 3$)$ in polluted estuary fish but not in 

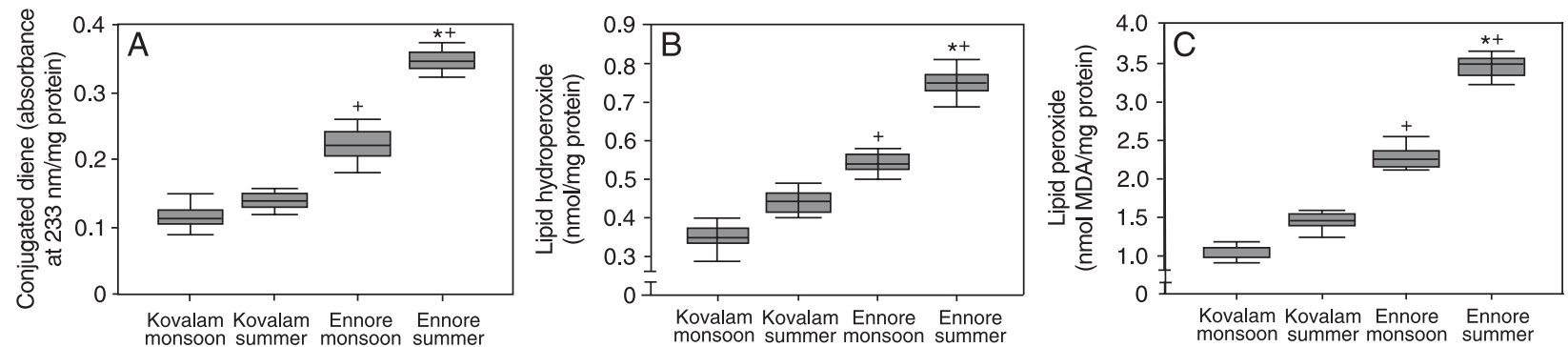

Figure 1. Liver lipid oxidation markers of Mugil cephalus from the polluted Ennore estuary and the unpolluted Kovalam estuary measured during the summer and monsoon seasons. Data are reported as means $\pm S D$. Conjugated dienes $(A)$, lipid hydroperoxide formed (B) and lipid peroxides formed $(C)$ are reported for 20 fish in each group. ${ }^{*} P<0.05$ compared to monsoon season for fish raised in a polluted estuary (Duncan multiple range test); ${ }^{+} \mathrm{P}<0.05$ comparison between fish raised in an unpolluted estuary and fish raised in a polluted estuary for both seasons (Duncan multiple range test). MDA = malondialdehyde.

Figure 2. Specific activity of the antioxidant enzymes superoxide dismutase (A) and catalase (B) in the liver homogenate of Mugil cephalus from the polluted Ennore estuary and the unpolluted Kovalam estuary. Data are reported as means \pm SD for 20 fish in each group. ${ }^{*} \mathrm{P}<0.05$ compared to polluted estuary fish during the monsoon season (Duncan multiple range test); ${ }^{+} \mathrm{P}<0.05$ comparison between unpolluted estuary fish and polluted estuary fish for each season (Duncan multiple range test).

Figure 3. Glutathione redox ratio in the liver homogenate of Mugil cephalus from the polluted Ennore estuary and the unpolluted Kovalam estuary. Data are reported as mean \pm SD for 20 fish in each group. ${ }^{*} \mathrm{P}<0.05$ comparison between seasons of fish raised in a polluted estuary (Duncan multiple range test); ${ }^{+} P<0.05$ comparison between unpolluted estuary fish and polluted estuary fish for both seasons (Duncan multiple range test).
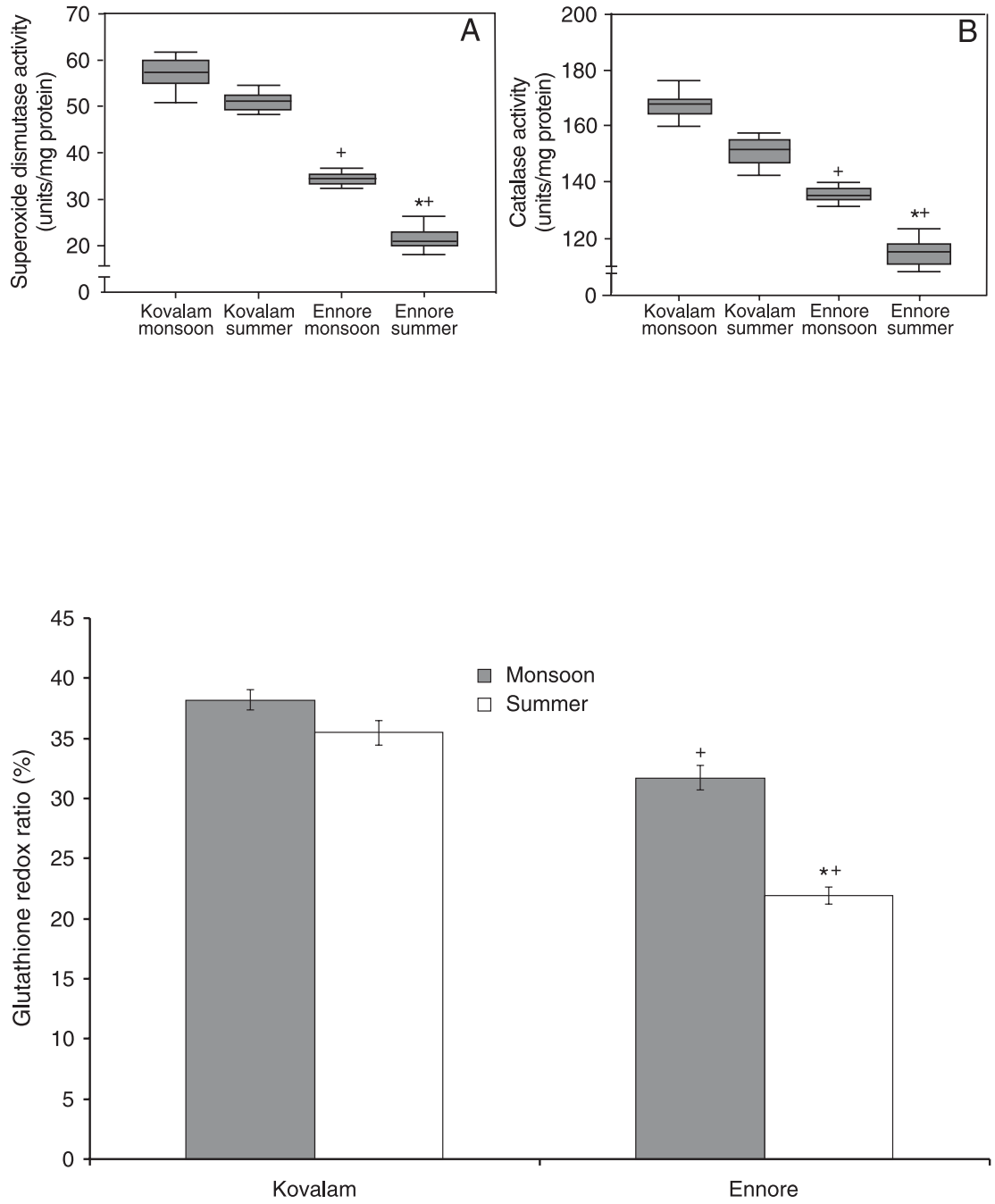
unpolluted estuary fish. Again, the decrease was significant $(P<0.05)$ in polluted estuary fish during the summer compared with the monsoon season, but a significant decrease was not observed in unpolluted estuary fish between seasons.

\section{Discussion}

Grey mullets, the natural inhabitant of the estuaries studied, are found in the shallow water of the intertidal zone that experiences dual fluctuations in both temperature and salinity. These economically important fish are under threat because of their continuous exposure to toxic chemical-rich industrial effluents that are discharged into the estuaries. These pollutants enter the fish through the gills; a main site of xenobiotic transfer followed by distribution throughout the entire body and their potential deleterious effect on target organs (18). Heavy metal contamination of the Ennore estuary and its significant accumulation in muscle tissue of fish inhabiting this estuary has been reported (9). In 1985, metal distribution in the Kovalam estuary water was reported to be in the normal range as recommended by the Indian Standards Institution (ISI) (19).

Heavy metals induce oxidative stress in fish (20) by generating reactive oxygen species by their participation in the Fenton reaction and by donating electrons to oxygen. Our data are consistent with this view. Fish inhabiting the highly polluted Ennore estuary developed an enhanced state of oxidative stress characterized by increased levels of lipid oxidation markers such as conjugated diene, lipid hydroperoxide, and lipid peroxide, similar to a response observed in fish under the same conditions (21).

The biological membrane that contains polyunsaturated fatty acid as its major constituent is considered to be the target for the reactive oxygen species-driven oxidation process (7). The significant increase in lipid oxidation markers may indicate the susceptibility of lipid molecules to reactive oxygen species and the extent of oxidative damage imposed on these molecules. The clear increase in lipid oxidation and its markers may also be due to the decrease in antioxidant enzyme activities. Accordingly, the antioxidant enzyme levels have been found to be decreased significantly in this study and a similar type of response has also been observed in fish such as Geophagus brasiliensis in response to oxidative stress $(8,22)$. Maintenance of high constitutive levels of antioxidant enzymes like superoxide dismutase and catalase is essential to prevent oxyradical-mediated lipid peroxidation (23). Longterm exposure of fish to pollutants may also be a possible reason for the decrease in antioxidant enzyme levels.

Superoxide dismutase is an enzyme that catalyzes the dismutation of superoxide $\left(\mathrm{O}_{2}^{--}\right)$to hydrogen peroxide $\left(\mathrm{H}_{2} \mathrm{O}_{2}\right)$. Decreased activity of this enzyme leads to the accumulation of $\mathrm{O}_{2}{ }^{-*}$, which in turn accelerates the conversion of $\mathrm{Fe}^{3+}$ to $\mathrm{Fe}^{2+}$. The latter serves as a substrate for hydroxyl radical $(\cdot \mathrm{OH})$-generating reaction leading to enhanced lipid peroxidation (24). Catalase plays a role in the decomposition of $\mathrm{H}_{2} \mathrm{O}_{2}$ to water. Reduced activity of this enzyme results in the accumulation of hydrogen peroxide increasing the production of hydroxyl radical via Fenton's reaction. Due to altered glutathione redox ratio and hence a decrease in reduced glutathione levels, the glutathionemediated detoxification process may also be affected. This might be a factor responsible for the lack of elimination of toxic compounds that enter the fish and thus result in their accumulation, aggravating oxidative stress. Various tissues of Liza macrolepis inhabiting the Ennore estuary have shown that the concentration of certain heavy metals such as mercury, cadmium, zinc, and iron exceeds the permissible safe levels proposed by the Industrial Toxicology Research Centre, Lucknow, India (25). Detoxification enzyme variations also exert negative effects such as increased susceptibility to reactive oxygen species formation, increased energetic demand, proliferation of cells, etc. (26).

Seasonal influence is an important parameter of marine environment (2). Its consideration is essential during biomonitoring programs and when sampling is done at different periods of the year. Strong seasonal variations in river flow, dissolved oxygen, $\mathrm{pH}$, temperature, salinity, and suspended particulate matter in the Western Scheldt estuary have been reported by Zwolsman (27). Seasonal variations in various hydrographic parameters have also been reported in the Ennore estuary (10). Levels of iron, zinc, manganese, and copper in water and sediment samples have shown seasonal fluctuations in the Ennore estuary $(9,28)$. The oxidative stress biomarkers determined in the present study of fish samples from Ennore estuary exhibited variations between seasons, suggesting the seasonal influence on these parameters in agreement with previous research $(10,28)$.

In conclusion, estimation of oxidative stress biomarkers in fish, as in the present study, could provide a useful indicator of pollution of water bodies (29). Since it is evident that seasonal changes play a key role in modulating oxidative stress in fish exposed to pollutants, this influence needs to be better understood in aquatic biomonitoring studies (8). 


\section{References}

1. Padmini E, Thendral Hepsibha B, Shanthalin Shellomith AS. Lipid alteration as stress markers in grey mullets (Mugil cephalus Linnaeus) caused by industrial effluents in Ennore estuary (oxidative stress in fish). Aquaculture 2004; 5: 115118.

2. Tait RV. Elements of marine ecology. An introductory course. 3rd edn. Massachusetts: Butterworth Publishers; 1981.

3. Raghunathan MB, Srinivasan M. Zooplankton dynamics and hydrographic features of Ennore estuary, Madras. Rec Zool Sur India 1983; 40: 1-30.

4. Adams SM, Shepard KL, Greeley MS Jr, Jimenez BD, Ryon MG, Shugart LR, et al. The use of bioindicators for assessing the effects of pollutant stress on fish. Mar Environ Res 1989; 28: 459-464.

5. Sies H. Oxidative stress: introductory remarks. In: Sies H (Editor), Oxidative stress. London: Academic Press; 1985. p 1-8.

6. Das S, Das DK. Antioxidant paradox. SFRR-India Bull 2006; 5: 8-11.

7. Abele D, Puntarulo S. Formation of reactive species and induction of antioxidant defence systems in polar and temperate marine invertebrates and fish. Comp Biochem Physiol A Mol Integr Physiol 2004; 138: 405-415.

8. Wilhelm Filho D, Torres MA, Tribess TB, Pedrosa RC, Soares $\mathrm{CH}$. Influence of season and pollution on the antioxidant defenses of the cichlid fish acara (Geophagus brasiliensis). Braz J Med Biol Res 2001; 34: 719-726.

9. Padmini E, Vijaya Geetha B. A comparative seasonal pollution assessment study on estuary with respect to metal accumulation in Mugil cephalus. Oceanol Hydrobiol Studies 2007; 35: 1-13.

10. Padmini E, Vijaya Geetha B. Seasonal influences on water quality parameters and pollution status of the Ennore estuary, Tamilnadu, India. J Environ Hydrol 2007; 15: 1-9.

11. Fischer W, Bianchi G. FAO species identification sheets for fishery purposes. Western Indian Ocean (fishing area 51). Vol. I-6. Rome: Food and Agricultural Organization of the United Nations; 1984.

12. Rao KS, Recknagel RO. Early onset of lipoperoxidation in rat liver after carbon tetrachloride administration. Exp Mol Pathol 1968; 9: 271-278.

13. Jiang ZY, Hunt JV, Wolff SP. Ferrous ion oxidation in the presence of xylenol orange for detection of lipid hydroperoxide in low density lipoprotein. Anal Biochem 1992; 202: 384389.

14. Ohkawa $\mathrm{H}$, Ohishi N, Yagi K. Assay for lipid peroxides in animal tissues by thiobarbituric acid reaction. Anal Biochem 1979; 95: 351-358.

15. Misra HP, Fridovich I. The role of superoxide anion in the autoxidation of epinephrine and a simple assay for superox- ide dismutase. J Biol Chem 1972; 247: 3170-3175.

16. Beers RF Jr, Sizer IW. A spectrophotometric method for measuring the breakdown of hydrogen peroxide by catalase. J Biol Chem 1952; 195: 133-140.

17. Hissin PJ, Hilf R. A fluorometric method for determination of oxidized and reduced glutathione in tissues. Anal Biochem 1976; 74: 214-226.

18. Buet $\mathrm{A}$, Barilloet $\mathrm{S}$, Camilleri $\mathrm{V}$. Changes in oxidative stress parameters in fish as response to direct uranium exposure. Radioprotection 2002; 40 (Suppl 1): S151-S155.

19. Fiji Ministry of Primary Industries. Research Division: Annual Report for the Year 1985. Fiji Parliamentary Paper; No. 79; 1986

20. Choi JH, Yu BP. Modulation of age related alteration of iron, ferritin, and lipid peroxidation. J Am Aging Assoc 1994; 17: 93-97.

21. Padmini E, Kavitha M. Contaminant induced stress impact on biochemical changes in brain of estuarine grey mullets. Pollution Res 2005; 24: 647-651.

22. Lenartova V, Holovska K, Pedrajas JR, Martinez-Lara E, Peinado J, Lopez-Barea J, et al. Antioxidant and detoxifying fish enzymes as biomarkers of river pollution. Biomarkers 1997; 2: 247-252.

23. Lushchak VI, Lushchak LP, Mota AA, Hermes-Lima M. Oxidative stress and antioxidant defenses in goldfish $\mathrm{Ca}$ rassius auratus during anoxia and reoxygenation. $A m \mathrm{~J}$ Physiol Regul Integr Comp Physiol 2001; 280: R100-R107.

24. Halliwell B, Gutteridge JMC. Free radicals in biology and medicine. Oxford: Clarendon; 1985.

25. Nammalwar P. Fish bioassay in the Cooum and Adyar estuaries for environmental management. In: Singh KP (Editor), Tropical ecosystems ecology and management. Delhi: Wiley Eastern; 1992. p 359-370.

26. Vander Oost R, Beyer J, Vermeulen NPE. Fish bioaccumulation and biomarkers in environmental risk assessment: a review. Environ Toxicol Pharmacol 2003; 13: 57-149.

27. Zwolsman JJG, Van Eck BTM, Vander Weijden $\mathrm{CH}$. Geochemistry of dissolved trace metals (cadmium, copper, and zinc) in the Scheldt estuary, southwestern Netherlands: impact of seasonal variability. Geochim Cosmochim Acta 1997; 61: 1635-1652.

28. Rajathy S, Azariah J. Spatial and seasonal variation in heavy metal iron, zinc, manganese and copper in the industrial region of the Ennore estuary, Madras. J Marine Biol 1996; 38: 68-78.

29. Pandey S, Parvez S, Sayeed I, Haque R, Bin-Hafeez B, Raisuddin S. Biomarkers of oxidative stress: a comparative study of river Yamuna fish Wallago attu (BI. \& Schn.). Sci Total Environ 2003; 309: 105-115. 